\title{
Kajian Fisika Kimia Perairan Danau Bangkau Sebagai Dasar Pengembangan Budidaya Ikan \\ Siswanto $^{1^{*}}$, Dini Sofarini ${ }^{1}$, Marissa Septa Hanifa ${ }^{1}$ \\ ${ }^{1}$ Prodi Budidaya Perairan Fakultas Perikanan dan Ilmu Kelautan \\ Universitas Lambung Mangkurat \\ Jl. A. Yani Km 36 Banjarbaru 70714 Kalimantan Selatan \\ *siswanto@ulm.ac.id \\ DOI: https://doi.org/10.21107/rekayasa.v14i2.11263
}

\begin{abstract}
Nowadays, in the Danau Bangkau swamp, there is a tendency that some types of fish are increasingly difficult to find and the size of the fish that are still available is relatively small, and the catch of fishermen has decreased. Utilization of fishery potential of Danau Bangkau swamp through the development of aquaculture business is an alternative option that must be implemented. This research was conducted to be able to see the feasibility of the water quality in the Danau Bangkau swamp so that hope it can be basic information for the development of aquaculture in that area. The results showed that the temperature range in the waters of the Danau Bangkau swamp was 28.3-32.4 ${ }^{\circ} \mathrm{C}$, the brightness was $72-95 \mathrm{~cm}$, degree of acidity $(\mathrm{pH}$ ) is 6.01-7.2, dissolved oxygen (DO) 1.2-4.3 mg/l, nitrate 0.7-9.8 mg/l, phosphate 0.2-3.31 mg/l and total suspended solids 7-48 mg/l. In general, the value of water quality parameters fulfill the quality standards, except for dissolved oxygen and phosphate parameters. The low levels of dissolved oxygen and high levels of phosphate indicated that there has been pollution in the Danau Bangkau swamp waters so it is not suitable for the cultivation activities.
\end{abstract}

Keywords : Danau Bangkau, aquaculture, water quality, quality standards

\section{PENDAHULUAN}

Kawasan Rawa Danau Bangkau dalam Rencana Tata Ruang Wilayah (RTRW) Provinsi Kalimantan Selatan diarahkan sebagai kawasan yang diprioritaskan pengembangannya sebagai kawasan pelestarian reservaat perikanan (fish stocking) yang perlu dilindungi dan dijaga kelestariannya. Rawa Danau Bangkau merupakan perairan yang memiliki daerah luas genangan yang bervariasi sepanjang tahun. Pada musim penghujan genangan air biasanya akan meluas ke lahan rawa banjiran dan pada musim kemarau air terperangkap di daerah rawa serta daerah galian atau kolam rawa (Chairuddin et al., 1999).

Areal sekeliling Rawa Danau Bangkau ini merupakan kawasan pemukiman serta areal penangkapan ikan bagi nelayan. Pemanfaatan rawa ini oleh masyarakat didominasi oleh kegiatan penangkapan ikan. Dewasa ini di perairan Rawa Danau Bangkau ada kecenderungan bahwa

\section{Article History:}

Received: May, $5^{\text {th }}$ 2021; Accepted: July, $30^{\text {th }} 2021$

Rekayasa ISSN: $2502-5325$ has been Accredited by Ristekdikti (Arjuna) Decree: No. 23/E/KPT/2019 August 8th, 2019 effective until 2023 beberapa jenis ikan sudah semakin sulit ditemukan dan ukuran ikan yang masih ada relatif kecil, serta hasil tangkapan nelayanpun mengalami penurunan. Menurut Rahman (2005), perairan rawa Danau Bangkau ditaksir memiliki ichthyomass > 1,5 ton/ha, namun pada tahun 2007 produksi ikan dari perairan tersebut diperkirakan hanya sebesar 0,75 ton/ha (Dinas Perikanan dan Kelautan Provinsi Kalimantan Selatan, 2007). Produksi perikanan tangkap yang berasal dari perairan rawa di Kalimantan Selatan pada kurun waktu tahun 2005-2007 memperlihatkan penurunan dari 60.245 ton menjadi 52.192 ton dengan total penurunan sebesar $13,36 \%$ atau dengan rata-rata penurunan $6,68 \%$ per tahun (Dinas Perikanan dan Kelautan Provinsi Kalimantan Selatan, 2007).

Penurunan ini disinyalir akibat intensitas penangkapan ikan yang tinggi serta pendangkalan perairan akibat gulma air (Dinas Perikanan Kabupaten Hulu Sungai Selatan, 2018). Menurut

\section{Cite this as:}

Siswanto., Sofarini, D \& Hanifa, S.M. (2021). Kajian Fisika Kimia Perairan Danau Bangkau sebagai Dasar Pengembangan Budidaya Ikan. Rekayasa 14 (2). 245-251. doi: https://doi.org/10.21107/rekayasa.v14i2. 11263. 
Wargasasmita (2005), penurunan populasi ikan disebabkan oleh adanya gangguan pada sistem ekologi, ada 6 kategori utama menurunnya keanekaragaman ikan air tawar dimana 2 diantaranya adalah eksplorasi yang berlebihan dan perubahan habitat. Pemanfaatan potensi perikanan rawa Danau Bangkau melalui pengembangan usaha budidaya perikanan merupakan alternatif pilihan yang harus dilaksanakan karena usaha penangkapan ikan telah mencapai tingkat pemanfaatan yang optimal. Penurunan catch per unit of effort sebagai indikasi kelebihan tangkap telah nampak nyata.

Menurut Dauhan et al., (2014), produktivitas dan kelangsungan hidup hewan air sangat dipengaruhi oleh faktor-faktor fisik kualitas air. Karena untuk mendapatkan ikan dengan pertumbuhan yang optimal, terhindar dari berbagai penyakit, maka diperlukan lingkungan dengan kualitas air yang baik dan mendukung kehidupan ikan. Oleh karena itu kualitas air merupakan faktor penentu utama dalam kegiatan budidaya perikanan yang berkaitan dengan produktivitas hewan akuatik. Beberapa faktor fisik yang menjadi parameter kualitas air dalam budidaya ikan air tawar diantaranya adalah suhu, pH, DO, Nitrat dan Ammonia (Marlina \& Rakhmawati, 2016).

Parameter-parameter kualitas air seperti suhu, DO, pH, Amonia dan Nitrat memiliki korelasi yang terkait dengan kualitas perairan (Marlina \& Rakhmawati, 2016). Penurunan atau naiknya nilai salah satu parameter diatas dapat mempengaruhi nilai parameter yang lain dan mempengaruhi kualitas perairan (Mas'ud, 2014). Beberapa hal ini tentunya menjadi alasan mutlak untuk malakukan pengawasan terhadap parameter kualitas air oleh para pembudidaya.

Oleh karena itu kiranya penelitian ini dilakukan untuk dapat melihat sejauh mana kelayakan kualitas air yang ada di rawa danau Bangkau sehingga harapannya dapat menjadi informasi dasar pengembangan perikanan budidaya di kawasan tersebut. Pengetahuan mengenai kondisi kualitas perairan rawa danau Bangkau yang dicerminkan oleh nilai konsenstrasi beberapa parameter kualitas air, baik secara fisika maupun secara kimia, sangat diperlukan untuk mengetahui seberapa layak perairan tersebut dijadikan sebagai kawasan budidaya ikan, sehingga harapannya dapat menunjang hasil produksi perikanan khususnya dari sektor budidaya, sehingga bisa mengurangi dampak dan menjadi solusi dari menurunnya hasil produksi perikanan tangkap di kawasan tersebut.

\section{METODE PENELITIAN \\ Tempat dan Waktu Penelitian}

Penelitian ini dilaksanakan selama 2 bulan di perairan Rawa Danau Bangkau Kabupaten Hulu Sungai Selatan Propinsi Kalimantan Selatan. Lokasi pengambilan sampel pada penelitian ini berjumlah 2 stasiun, yaitu kawasan tengah (stasiun 1) dan outlet (stasiun 2). Pemilihan lokasi tersebut dilakukan secara purposive sampling. Pengambilan sampel itu sendiri dilakukan pada bulan Juli dan Agustus 2020, yang dilakukan setiap 15 hari sekali dengan total 3 kali pengambilan sampel. Pemilihan pengambilan sampel dapat merepresentasikan kondisi kualitas air di perairan tersebut.

\section{Pengukuran In Situ}

Pengukuran kualitas air yang dilakukan secara in-Situ adalah suhu, kecerahan, $\mathrm{pH}$ dan oksigen terlarut. Pengukuran tersebut menggunakan alat Water Quality Checker merek Horiba U-52 dan Secchi disk.

\section{Analisis Laboratorium}

Parameter padatan tersuspensi total (TSS), nitrat dan Fosfat dilakukan di laboratorium dengan metode spektro-fotometri. Cara pengambilan sampel menggunakan botol air mineral steril berdasarkan SNI 6989.57 (2008). Sampel air dimasukkan kedalam botol yang sudah diberi tanda sesuai stasiun pengambilan sampel, lalu dimasukkan kedalam cooler box dalam perjalanan menuju laboratorium kualitas air Fakultas Perikanan dan Kelautan Universitas Lambung Mangkurat.

\section{Analisis Data}

Data dari hasil pengukuran kualitas air rawa Danau Bangkau dibandingkan dengan kriteria baku mutu kualitas air untuk budidaya yang tercantum dalam Peraturan Pemerintah Nomor 82 Tahun 2001 tentang Pengelolaan Kualitas Air dan Pengendalian Pencemaran Air, khususnya Kelas III setelah itu data dianalisis secara deskriptif.

\section{HASIL DAN PEMBAHASAN \\ Kualitas Fisika Kimia Perairan}

Hasil pengukuran kualitas fisika kimia perairan dan analisis laboratorium kualitas air dapat dilihat pada Tabel 1. 
Tabel 1. Hasil Pengukuran Kualitas Fisika Kimia Perairan di Danau Bangkau

\begin{tabular}{|c|c|c|c|c|}
\hline Parameter & Satuan & Kisaran & Keterangan & Baku Mutu \\
\hline Suhu & ${ }^{\circ} \mathrm{C}$ & $28,3-32,4$ & In-Situ & $\begin{array}{c} \pm 3^{\circ} \mathrm{C} \text { dari suhu normal } \\
\text { alamiah (Deviasi } 3)^{*}\end{array}$ \\
\hline Kecerahan & $\mathrm{cm}$ & $72-95$ & In-Situ & $>30^{* *}$ \\
\hline Derajat Keasaman $(\mathrm{pH})$ & - & $6,01-7,2$ & In-Situ & $6-9^{*}$ \\
\hline Oksigen Terlarut (DO) & $\mathrm{mg} / \mathrm{l}$ & $1,2-4,3$ & In-Situ & Minimal 3* \\
\hline Nitrat & $\mathrm{mg} / \mathrm{l}$ & $0,7-9,8$ & Analisis Laboratorium & $20^{*}$ \\
\hline Fosfat & $\mathrm{mg} / \mathrm{l}$ & $0,2-3,31$ & Analisis Laboratorium & $1^{*}$ \\
\hline $\begin{array}{l}\text { Padatan Tersuspensi } \\
\text { Total (TSS) }\end{array}$ & $\mathrm{mg} / \mathrm{l}$ & $7-48$ & Analisis Laboratorium & $400 *$ \\
\hline 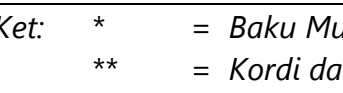 & $\begin{array}{l}\text { No. } 827 \\
(2009)\end{array}$ & 2001 & & \\
\hline
\end{tabular}

\section{Suhu}

Kisaran suhu rawa danau Bangkau berkisar antara $28,3^{\circ} \mathrm{C}-32,4^{\circ} \mathrm{C}$. Suhu rawa danau Bangkau termasuk suhu optimum untuk budidaya ikan. Hal ini selaras dengan pernyataan Aisyah dan Subehi (2012); Tatangindatu et al., (2003); Kordi dan Tancung (2007), yang menyatakan bahwa nilai suhu yang optimum untuk budidaya perikanan berkisar antara $27^{\circ} \mathrm{C}-32^{\circ} \mathrm{C}$. Jika dibandingkan dengan Peraturan Pemerintah Republik Indonesia Nomor 82 Tahun 2001 tentang Pengelolaan Kualitas Air dan Pengendalian Pecemaran air tentang baku mutu suhu air untuk kelas III yaitu deviasi 3, yang artinya jika suhu normal $29-30^{\circ} \mathrm{C}$, maka kriteria kelas III membatasi suhu air di kisaran $26-33^{\circ} \mathrm{C}$ (Hanisa, 2017). Dengan demikian maka suhu air rawa danau Bangkau masih dapat menunjang kehidupan di perairan. Suhu sangat berpengaruh terhadap pertumbuhan dan kehidupan biota air. Secara umum, laju pertumbuhan meningkat sejalan dengan kenaikan suhu. Menurut Kordi dan Andi (2009), peningkatan suhu sampai ekstrim (drastis) dapat menekan kehidupan hewan budidaya bahkan menyebabkan kematian.

\section{Kecerahan}

Kisaran kecerahan rawa danau Bangkau berkisar antara $72 \mathrm{~cm}-95 \mathrm{~cm}$. Menurut Kordi dan Andi (2009), kecerahan yang baik bagi usaha budidaya ikan berkisar $30-40 \mathrm{~cm}$ yang diukur menggunakan secchi disk. Kecerahan adalah parameter fisika yang erat kaitannya dengan proses fotosintesis pada suatu ekosistem perairan. Kecerahan yang tinggi menunjukkan daya tembus cahaya matahari yang jauh kedalam perairan begitu pula sebaliknya. Berdasarkan hasil penelitian maka kecerahan rawa danau Bangkau sudah sesuai untuk kegiatan budidaya.

Menurut Sukadi (2011), nilai optimal kecerahan air untuk budidaya ikan nila di waduk berkisar tidak kurang dari $60 \mathrm{~cm}$. Kekeruhan yang tinggi (atau kecerahan yang rendah) dapat menyebabkan terganggunya sistem osmoregulasi seperti pernafasan dan daya lihat organisme akuatik, serta dapat menghambat penetrasi cahaya ke dalam air.

\section{Derajat Keasaman (pH)}

Jika dibandingkan dengan baku mutu kualitas air dalam Peraturan Pemerintah Republik Indonesia Nomor 82 Tahun 2001 tentang Pengelolaan Kualitas Air dan Pengendalian Pecemaran Air Kelas III, $\mathrm{pH}$ rawa danau Bangkau sesuai untuk kegiatan budidaya yang dimana nilainya berkisar antara 6,01 - 7,2. Titik kematian ikan pada $\mathrm{pH}$ asam adalah 4 dan pada pH basa adalah 11 (Lesmana, 2002). Pada umumnya ikan air tawar dapat hidup dengan baik pada $\mathrm{pH}$ sedikit asam berkisar 6,5-8, sementara keasaman air untuk perkembangbiakan ikan yang baik berkisar $6,4-7,0$ sesuai jenis ikan sedangkan kisaran $\mathrm{pH}$ optimal untuk ikan berkisar $6,5-8,5$.

\section{Oksigen Terlarut (DO)}

Dari hasil pengukuran kisaran oksigen terlarut rawa danau Bangkau adalah 1,2 - 4,3 mg/l. Nilai oksigen terlarut di rawa danau Bangkau dibandingkan dengan baku mutu kualitas air yang diatur dalam Peraturan Pemerintah Republik Indonesia Nomor 82 Tahun 2001 tentang Pengelolaan Kualitas Air dan Pengendalian Pecemaran air, tidak sesuai dengan baku mutu untuk budidaya. Nilai oksigen terlarut pada saat sampling terakhir di stasiun 2 (outlet) sempat tinggi dengan nilai $4,3 \mathrm{mg} / \mathrm{l}$, namun apabila ditarik nilai 
rata-rata dari 3 kali sampling, nilai oksigen terlarut hanya berkisar 2,57 sedangkan di stasiun 1 (tengah) nilai rata-rata oksigen terlarut adalah 1,73 mg/l.

Nilai ini tidak memenuhi baku mutu standar yang ditetapkan oleh pemerintah melalui Peraturan Pemerintah Republik Indonesia Nomor 82 Tahun 2001 untuk kelas III (budidaya) yaitu minimal 3 mg/l. Menurut Tyas dkk., (2016), apabila oksigen terlarut kurang dari $1 \mathrm{mg} / \mathrm{l}$ dan dalam jangka waktu yang lama, maka akan menyebabkan kematian pada ikan, sedangkan oksigen terlarut kurang dari $5 \mathrm{mg} / \mathrm{l}$ akan mengakibatkan lambatnya pertumbuhan ikan.

Meskipun beberapa jenis ikan mampu bertahan hidup pada perairan dengan kandungan oksigen terlarut < 3 ppm, namun kosentrasi yang baik dalam budidaya perairan adalah 5-7 ppm. Hanya ikan-ikan yang memiliki alat pernapasan tambahan yang mampu hidup pada perairan yang kandungan oksigen rendah, seperti lele, gurami, sepat, betok dan gabus (Kordi dan Tancung, 2007). Hal ini sejalan dengan hasil penelitian Rahman et al., (2010), yang melaporkan bahwa keragaman jenis organisme nektonik (ikan) di kawasan perikanan beje di Rawa Danau Bangkau tergolong rendah dan didominasi ordo Labyrinthici, dengan jenis ikan yang ditemukan adalah: gabus (Channa striata Blkr), betok (Anabas testudienus Bloch), tambakan (Helostoma temincki CV), sepat siam (Trichogaster pectoralis Regan) dan sepat rawa (Trichogaster trichopterus).

\section{Nitrat}

Baik stasiun 1 maupun stasiun 2, terlihat ditumbuhi gulma air seperti enceng gondok (Eiclzhornia crassipes). Alaerst dan Sartika (1987), menyatakan bahwa nitrat merupakan bentuk nitrogen yang utama pada perairan alami sebagai salah satu nutrien yang penting untuk pertumbuhan alga dan tumbuhan air lainya, sehingga konsentrasi nitrat yang melimpah dapat menstimulasi pertumbuhan dan perkembangan bagi organisme perairan khususnya alga (fitoplankton) bila didukung oleh ketersediaan nutrien lainnya.

Dari hasil analisis laboratorium, kisaran nitrat di perairan rawa danau Bangkau adalah 0,7 - 9,8 mg/l. Hasil analisis nitrat jika dibandingkan dengan baku mutu pada Peraturan Pemerintah Nomor 82 Tahun 2001 untuk kelas III (pembudidayaan ikan air tawar) tidak melebihi batas minimum baku mutu yang memiliki nilai maksimal 20 mg/l. Menurut Tambaru dan Samawi (1996), kebutuhan nitrat oleh setiap alga sangat beragam, apabila kadar nitrat dibawah 0,1 atau diatas $45 \mathrm{mg} / \mathrm{l}$, maka nitrat merupakan faktor pembatas berarti pada kadar demikian nitrat bersifat toksik. Nitrat di alam dapat dihasilkan secara alami maupun dari aktivitas manusia. Sumber alami nitrat adalah dari siklus nitrogen sedangkan sumber yang berasal dari aktivitas manusia adalah penggunaan pupuk nitrogen, limbah industri dan limbah organik manusia (Setiowati dan Wahyuni, 2016). Konsentrasi nitrat di rawa danau Bangkau yang memiliki nilai cukup tinggi diduga karena hasil buangan limbah domestik masyarakat yang bermukim di sekitar danau

\section{Fosfat}

Berdasarkan hasil analisis, kisaran fosfat yaitu 0,2 - 3,31 mg/l jika dibandingkan dengan baku mutu kualitas air yang diatur dalam Peraturan Pemerintah Nomor 82 Tahun 2001 tentang Pengelolaan Kualitas Air dan Pengendalian Pencemaran Air, khususnya kelas III untuk usaha budidaya, sudah melebihi batas yang dianjurkan. Batas maksimal yang dianjurkan adalah $1 \mathrm{mg} / \mathrm{l}$, sedangkan nilai rata-rata fosfat di stasiun 1 (tengah) adalah 1,35 dan stasiun 2 (outlet) adalah 0,32. Sumber fosfat di rawa danau Bangkau diduga berasal dari limbah rumah tangga seperti detergen dari buangan mesin cuci maupun cuci piring, yang yang berasal dari pemukiman masyarakat sekitar yang mendiami sekitaran rawa danau Bangkau yang akhirnya terbawa ke wilayah danau. Hal ini sesuai dengan hasil penelitian Endarini (2004); Soerjani (2009), salah satu sumber meningkatnya nutrien fosfat di perairan adalah pemasukan dari limbah cair domestik.

\section{Total Padatan Tersuspensi (TSS)}

Berdasarkan hasil analisis di laboratorium kisaran total padatan tersuspensi (TSS) yaitu 7 - 48 $\mathrm{mg} / \mathrm{l}$. Jika dibandingkan dengan baku mutu kualitas air dalam Peraturan Pemerintah Republik Indonesia Nomor 82 Tahun 2001 tentang Pengelolaan Kualitas Air dan Pengendalian Pecemaran Air, Kelas III. Total padatan tersuspensi di rawa danau Bangkau tidak melampaui batas baku mutu, maka memenuhi syarat kualitas air untuk budidaya. Keberadaan residu tersuspensi dalam air tidak diinginkan karena alasan menurunnya estetika air disamping residu tersuspensi dapat menjadi tempat penyerapan bahan kimia atau biologi seperti 


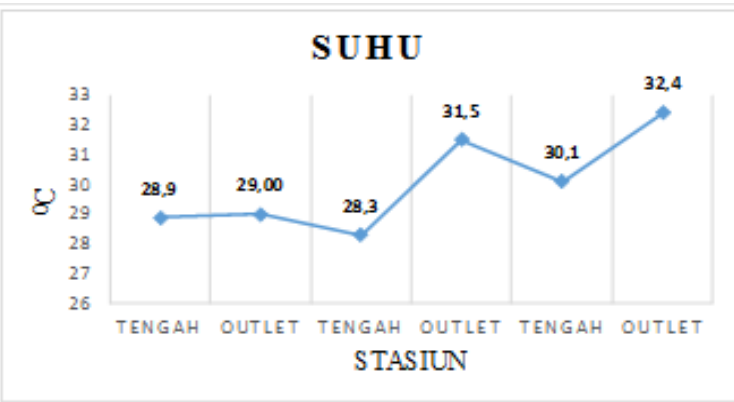

(a)

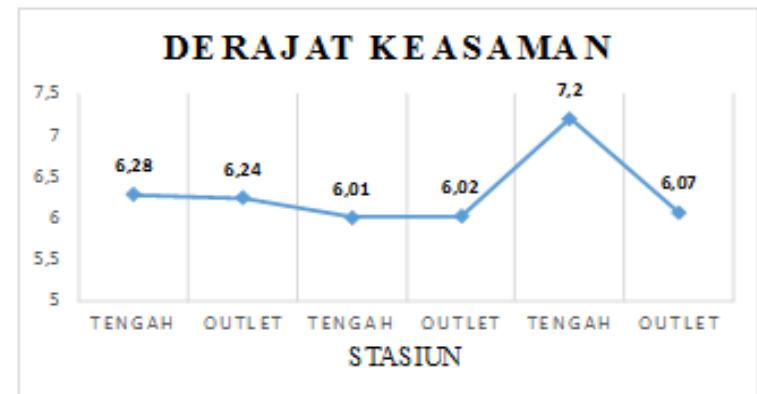

(c)

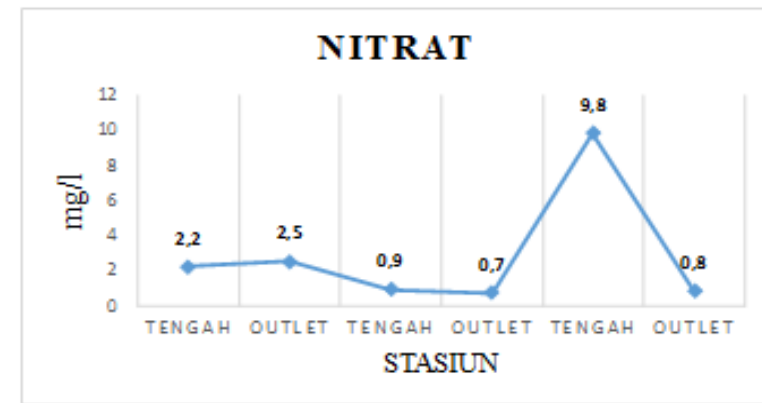

(e)

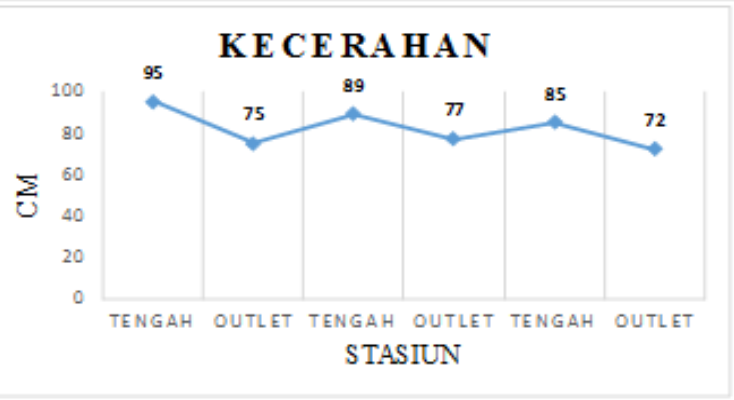

(b)

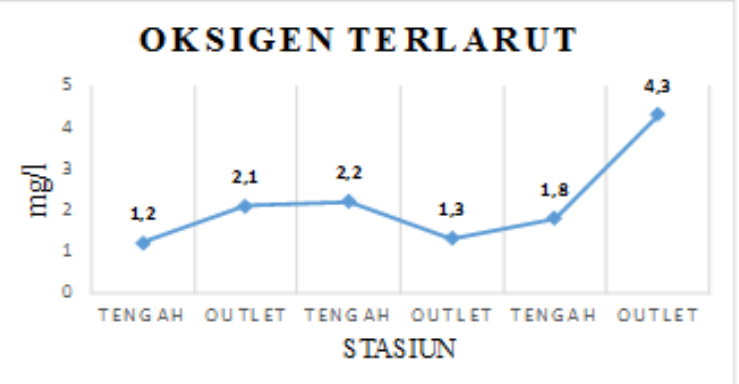

(d)

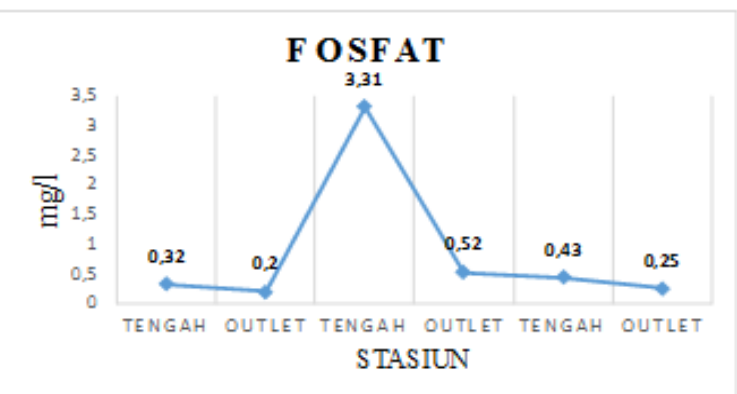

(f)

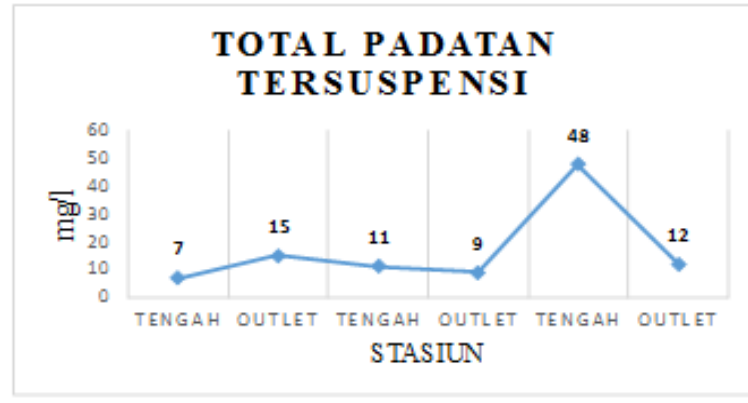

(g)

Gambar 1. Diagram hasil pengukuran dan analisis nilai fisika kimia perairan rawa danau Bangkau, (a) suhu, (b) kecerahan, (c) derajat keasaman, (d) oksigen terlarut, (e) nitrat, (f) fosfat dan (g) total padatan tersuspensi/TSS

mikroorganisme penyebab penyakit (Sunu dan Putra, 2001).

\section{Pengaruh Kualitas Fisika Kimia Perairan} terhadap Usaha Budidaya
Kualitas air di rawa danau Bangkau sebagian sesuai baku mutu kualitas air untuk budidaya namun ada pula yang tidak sesuai seperti oksigen terlarut (DO) dan fosfat, padahal oksigen terlarut adalah salah satu parameter kunci dalam kegiatan pembudidayaan ikan. Hal ini membuat ikan-ikan 
Tabel 2. Baku Mutu Air Beberapa Jenis Ikan Ekonomis Budidaya

\begin{tabular}{|c|c|c|c|c|c|}
\hline \multirow{2}{*}{\multicolumn{2}{|c|}{ Jenis Ikan }} & \multicolumn{4}{|c|}{ Parameter } \\
\hline & & \multirow{2}{*}{$\begin{array}{c}\text { Suhu }\left({ }^{\circ} \mathbf{C}\right) \\
25-30\end{array}$} & \multirow{2}{*}{$\frac{\mathbf{p H}}{6,5-8,5}$} & \multirow{2}{*}{$\begin{array}{c}\mathrm{DO}(\mathrm{mg} / \mathrm{l}) \\
>5\end{array}$} & \multirow{2}{*}{$\begin{array}{c}\text { Kecerahan } \mathbf{( c m )} \\
10-30\end{array}$} \\
\hline & Benih & & & & \\
\hline IVlas & Besar & $25-30$ & $6,5-8,5$ & $>5$ & $50-70$ \\
\hline \multirow{2}{*}{ Nila } & Benih & $25-30$ & $6,5-8,5$ & $>5$ & $30-40$ \\
\hline & Besar & $25-30$ & $6,5-8,5$ & $>5$ & $30-40$ \\
\hline \multirow{2}{*}{ Lele } & Benih & $25-30$ & $6,5-8,5$ & $>4$ & $25-35$ \\
\hline & Besar & $25-30$ & $6,5-8,5$ & $>4$ & $25-35$ \\
\hline \multirow{2}{*}{ Gurame } & Benih & $25-30$ & $6,5-8,5$ & $>3$ & $40-60$ \\
\hline & Besar & $25-30$ & $6,5-8,5$ & $>3$ & $40-60$ \\
\hline \multirow{2}{*}{ Patin } & Benih & $25-28$ & $6,5-8,5$ & $>5$ & $30-50$ \\
\hline & Besar & $27-32$ & $6,5-8,5$ & $>3$ & $50-70$ \\
\hline \multirow{2}{*}{ Udang Galah } & Benih & $28-30$ & $6,5-8,5$ & $>5$ & $50-70$ \\
\hline & Besar & $28-30$ & $6,5-8,5$ & $>5$ & $70-100$ \\
\hline
\end{tabular}

Sumber: BBPBAT (2016)

ekonomis yang biasanya dibudidayakan secara umum kemungkinan besar tidak akan bisa bertahan dalam kondisi perairan rawa danau Bangkau. Untuk lebih jelasnya baku mutu kualitas air untuk beberapa ikan ekonomis budidaya dapat dilihat pada Tabel 2.

Dari tabel dapat terlihat bahwa semua jenis ikan membutuhkan baku mutu untuk oksigen terlarut diatas $3 \mathrm{mg} / \mathrm{l}$, sedangkan kisaran oksigen terlarut di rawa danau Bangkau adalah 1,2 sampai 4,3 mg/l. Di saat sampling ketiga pada stasiun 2 (outlet) memang nilainya memenuhi baku mutu yaitu 4,3 $\mathrm{mg} / \mathrm{l}$, namun apabila diambil rata-rata dari keseluruhan sampling nilainya hanya $2,57 \mathrm{mg} / \mathrm{l}$ sedangkan untuk stasiun 1 (tengah) nilai rataratanya adalah $1,7 \mathrm{mg} / \mathrm{l}$. Parameter kualitas air oksigen terlarut (DO) sangat berpengaruh nyata terhadap kegiatan budidaya ikan. Kekurangan oksigen terlarut dapat memperlambat pertumbuhan ikan bahkan menyebabkan kematian. Menurut Ginting (2011), rendahnya konsentrasi oksigen terlarut apalagi jika sampai batas nol akan menyebabkan ikan dan fauna lainnya tidak bisa hidup dengan baik dan mati.

\section{KESIMPULAN}

Secara umum nilai parameter kualitas air memenuhi standar baku mutu menurut Peraturan Pemerintah Nomor 82 Tahun 2001 tentang Pengelolaan Kualitas Air dan Pengendalian Pencemaran Air untuk Kelas III, kecuali parameter oksigen terlarut (DO) dan fosfat. Rendahnya kadar oksigen terlarut serta tingginya kadar fosfat mengindikasikan bahwa telah terjadi pencemaran di perairan rawa danau Bangkau sehingga kurang baik digunakan untuk aktivitas budidaya.

\section{DAFTAR PUSTAKA}

Aisyah S, Subehi L. (2012). Pengukuran dan Evaluasi dalam Rangka Mendukung Pengelolaan Perikanan di Danau Limboto. Prosiding Seminar Nasional Limnology VI. Bogor.

Alaerst G, Sartika S. (1987). Metode Penelitian Air. Usaha Nasional. Surabaya.

Anonymous. (2009). Teknologi Pengelolaan Kualitas Air. Vedca Seamolec.

Chairuddin G, Rahman M, Masyhuri A, Husin S. (1999). Usaha budidaya mina unggas itik ala-bio dengan ikan betutu (Oxeleotris marmorata). Laporan penelitian. 134 hal.

Dauhan R. E. S., Efendi E., Suparmono. (2014). Efektifitas Sistem Akuaponik Dalam Mereduksi Konsentrasi Amonia Pada Sistem Budidaya Ikan. E-Jurnal Rekayasa dan Teknologi Budidaya Perairan.Vol. 3 No. 1.

Dinas Perikanan dan Kelautan Provinsi Kalimantan Selatan. (2007). Laporan Tahunan Dinas Perikana dan Kelautan Provisi Kalimantan Selatan 2006, Banjarmasin.

Dinas Perikanan Kabupaten Hulu Sungai Selatan. (2018). Laporan Tahunan Dinas Perikanan Kabupaten Hulu Sungai Selatan 2017, Kandangan.

Endarini T. (2004). Dampak Kegiatan Masyarakat Pada Kualitas Air Danau Buyan, Kabupaten 
Buleleng, Bali. Program Pascasarjana Universitas Indonesia. Jakarta.

Ginting, O. (2011). Studi Korelasi Kegiatan Budidaya Ikan dalam Keramba Jaring Apung dengan Pengkayaan Nutrien dan Chlorofil-a di Danau Toba. Tesis. Program Pasca Sarjana. Fakultas Matematik dan Ilmu Pengetahuan Alam. Universitas Sumatera Utara. Medan. 70 hal.

Hanisa, E., W.D. Nugraha, dan A. Sarminingsih. (2017). Penentuan Status Mutu Air Sungai Berdasarkan Metode Indeks Kualitas AirNational Sanitation Foundation (IKA-NSF) Sebagai Pengendalian Kualitas Lingkungan. Jurnal Teknik Lingkungan, Vol. 6, Nomor 1.

Kordi, M.G.H, Andi, B.T. (2009). Pengelolaan Kualitas Air dalam Budidaya Perairan. PT Rineka Cipta. Jakarta.

Kordi, M.G dan A.B. Tancung. (2007). Pengelolaan Kualitas Air Dalam Budidaya Perairan. Penerbit Rineka Cipta. Jakarta. $208 \mathrm{Hal}$.

Lesmana, D.S. (2002). Kualitas Air Untuk Ikan Hias Air Tawar.

Marlina E., Rakhmawati. (2016). Kajian Kandungan Ammonia Pada Budidaya Ikan Nila (Oreochromis niloticus) Menggunakan Teknologi Akuaponik Tanaman Tomat (Solanum lycopersicum) Prosiding Seminar Nasional Tahunan Ke-V Hasil-Hasil Penelitian Perikanan dan Kelautan. 181-187.

Mas'ud, F. (2014). Pengaruh Kualitas Air Terhadap Pertumbuhan Ikan Nila (Oreochromis sp.) Di Kolam Beton Dan Terpal. Grouper Faperik.

Peraturan Pemerintah Nomor 82 Tahun 2001. Tentang Pengelolaan Kualitas Air dan Pengendalian Pencemaran Air. Jakarta.

Rahman, M. (2005). Perkiraan Potensi Lestari Sumberdaya Ikan Perairan Rawa Danau Bangkau. Fakultas Perikanan. Banjarbaru.

Rahman, M., A.R. Bandung., dan Herliwati. (2010). Karakteristik Eko-Biologis Perikanan Beje di
Kawasan Rawa Danau Bangkau Kalimantan Selatan. Fakultas Perikanan Universitas Lambung Mangkurat. Banjarbaru.

Setiowati, R., dan E.T. Wahyuni, (2016). Monitoring Kadar Nitrit dan Nitrat pada air sumur di daerah Catur Tunggal Yogyakarta dengan Metode Spctrofotometris UV VIS. Jurnal Manusia dan Lingkungan. pp. 143-148.

SNI 6989.57. (2008). Air dan Air Limbah Bagian 57: Metoda Pengambilan Contoh Air Permukaan. Badan Standarisasi Nasional. Indonesia.

Soerjani, M. (2009). Dampak Kegiatan Masyarakat pada Kualitas Air Danau Buyan, Buleleng. Program Pascasarjana Universitas Indonesia. Jakarta.

Sukadi. (2011). Petunjuk Teknis Budidaya Ikan Dalam Keramba Jaring Apung. Pusat Penelitian dan Pengembangan Perikanan. Jakarta.

Sunu, P., dan R.M.S. Putra. (2001). Melindungi Lingkugan dengan Menerapkan ISO 14001. Gramedia WidiasaranaIndonesia.

Tambaru, R., dan F. Samawi. (1996). Beberapa Parameter Kimia Fisika Air di Muara Sungai Tallo Kota Makassar. TORANI Universitas Hasanuddin. Makassar.

Tatangindatu, F., Kalesaran, O., Rompas, R. (2013). Studi Parameter Fisika Kimia Air pada Areal Budidaya Ikan di Danau Tondano, Desa Paleloan, Kabupaten Minahasa.

Tyas, Nanik Mustikaning., Batu, Djamar Tumpal Floranthus Lumban., Affandi, Ridwan,. (2016). The Lethal Toxicity Test of $\mathrm{Cr}^{+}$on (Oreochromis niloticus). Jurnal Ilmu Pertanian Indonesia. Vol. 21(2). Hal. 32-128.

Wargasasmita, S. (2005). Ancaman Invasi Ikan Asing Terhadap Keanekaragaman Ikan Asli. Jurnal Iktiologi Indonesia. Vol. 5 No.1: 510. 
Rekayasa, 14 (2): 2021 | 231 